\title{
Editorials
}

\section{Anesthesiology, the birth of pharmacogenetics and Werner Kalow}

\author{
Jørgen Viby-Mogensen MD DMSC FRCA
}

"To whom who devotes his life to science, nothing can give more happiness than increasing the number of discoveries, but his cup of joy is full, when the results of his studies immediately find practical application."

Louis Pasteur

I

$\mathrm{N}$ this issue of the Journal, Werner Kalow, one of the founding fathers of pharmacogenetics, writes a fascinating historical account of how, half a century ago, he and others identified plasma cholinesterase (pseudocholinesterase) and discovered how some people are born with a defective enzyme that renders them incapable of hydrolyzing succinylcholine in the usual way. ${ }^{1}$

His recollections are not just of interest because they place anesthesiology on centre stage in connection with the birth of pharmacogenetics, but also because they offer an excellent insight into post-war researchers' working conditions, and not least of all illustrate the technical obstacles which confronted them. Kalow highlights several typical dilemmas surrounding medical research, and as such his article also offers a message to today's younger researchers. For example: that research seldom follows one predetermined pathway, but is intuitive and full of surprises; that chance encounters often lead a researcher into a particular area of investigation and later to a decisive new revelation; that, often as not, a cognitive breakthrough occurs simultaneously within different research groups, but also that years of hard work usually precede this breakthrough; that teamwork is important, also internationally, and with other centres and specialists; that a thorough knowledge of the literature is vital; and last but not least, that it is important to publish as quickly as possible if one wants to claim the honour of being first.
Kalow and his colleagues' proof that some patients have a genetically determined defect in plasma cholinesterase - a so-called dibucaine resistant enzyme, or atypical enzyme that causes an abnormal reaction to succinylcholine - had a significant impact on both laboratory and clinical research. The new knowledge stimulated enormous interest in plasma cholinesterase, particularly amongst biochemists and anesthesiologists, and several cholinesterase research centres around the world were established. ${ }^{2,3}$ In the intervening years many new biochemical methods for classifying plasma cholinesterase activity and phenotypes have been introduced. ${ }^{4-8}$ Nonetheless, Kalow's dibucaine inhibition percentage method remains the 'gold standard' for the classification of phenotypes. Kalow's method has undoubtedly stood the test of time, which is more than can be said for most diagnostic tests developed in the 1950s. However, with modern molecular biology testing procedures it is now relatively easy to classify the genotype of a patient's plasma cholinesterase with great accuracy. ${ }^{9-12}$ One can foresee that these procedures will soon supersede Kalow's dibucaine inhibition percentage method - also in the more routine investigations of patients' plasma cholinesterase.

Laboratory research was not the only area stimulated by Kalow's discovery, which also had a major impact on clinical research. Laboratory researchers and anesthesiologists found themselves working closely together with the aim of elucidating the clinical importance of the different phenotypes. ${ }^{13}$ This was a good example of 'translational research' long before the modern research community coined the phrase.

Today, even though we still do not fully understand plasma cholinesterase's physiological function, this cooperation has meant that our knowledge has

From the Department of Anaesthesia and Intensive Care, Copenhagen University Hospital, Copenhagen, Denmark.

Address correspondence to: Dr. Jørgen Viby-Mogensen, Department of Anaesthesia and Intensive Care, Copenhagen University Hospital, HS Rigshospitalet, DK-2100 Copenhagen, Denmark. Phone: 45-35-45-34-74; Fax: 45-35-45-29-50; E-mail: viby@rh.dk 
expanded greatly in respect of the gradual discovery of more than 40 mutations of plasma cholinesterase and their significance for the reactions to succinylcholine and mivacurium. In this respect we can now almost certainly decide whether an apparently abnormal reaction to succinylcholine or mivacurium is the result of a genetic defect in plasma cholinesterase, or that the cause needs to be found elsewhere in the management of the patient.

What may be even more significant is that it is possible to predict how a patient with a specific mutation in plasma cholinesterase will react to these two neuromuscular blocking agents. This knowledge currently enables us to offer well-qualified advice to persons that have a genetic defect in plasma cholinesterase and, for example, allows us to issue these persons with warning cards advising against the use of succinylcholine and mivacurium in normal doses. There are many patients and their relatives worldwide who are extremely thankful that it is possible to offer this type of investigation. A good example of this is that in Denmark 5,000 patients are carrying a warning card with information on the person's cholinesterase genotype and details of their anticipated reaction to succinylcholine and mivacurium. Last but not least, prospective controlled clinical trials have demonstrated how clinicians should treat patients with prolonged neuromuscular block after injection of succinylcholine or mivacurium. In particular this research has shown the importance of a rapid and accurate diagnosis so as to keep the patient anesthetized until muscle function returns to normal. ${ }^{\mathrm{A}, \mathrm{B}}$

With the decreasing use of neuromuscular blocking agents in general, and succinylcholine in particular, the genetically inherited mutations in plasma cholinesterase will naturally come to play a less significant role in an anesthesiologist's daily clinical routine. Evidence of this can be seen from the decline in the number of patients referred to the Danish Cholinesterase Research Unit as a result of a prolonged reaction to the effects of succinylcholine or mivacurium. However, as long as there is no really good replacement for these drugs, the informed anesthesiologist needs to know not just of the existence of

A Jensen FS. Plasma cholinesterase and the anaesthetist. New Aspects of Genetic Variants and Response to Succinylcholine. Ph.d. thesis, Copenhagen University, Copenhagen, Denmark, 1994.

B Gätke MR. Mutations in the Butylcholinesterase Gene and Their Significance for the Reaction to Mivacurium. Ph.d. thesis, Copenhagen University, Copenhagen, Denmark, 2001. the genetically inherited mutations, but also what this means and how a patient that reacts abnormally to succinylcholine or mivacurium should be treated. ${ }^{\mathrm{A}, \mathrm{B}}$

Of course, the introduction of new drugs within anesthesiology, whose biotransformation is plasma cholinesterase linked, can never be discounted in the future. However, this is not likely considering the many other options that are available today for synthesizing drugs that are not hydrolyzed by potentially genetically mutated enzymes. For this reason it seems clear that in 50 years time Kalow's discovery and his dibucaine inhibition method for classifying the plasma cholinesterase phenotypes will only be of historical interest to anesthesiologists. But how many discoveries and methodologies equal in stature to Werner Kalow's remain valuable after 50 years? The answer is: not many - which puts the importance of his scientific contribution into its rightful perspective.

\section{L'anesthésiologie, la naissance de la pharma- cogénétique et Werner Kalow}

"À celui qui consacre sa vie à la science, rien ne peut apporter plus de joie que d'angmenter le nombre des découvertes, mais il est au comble du bonbeur quand les résultats de ses études ont une application pratique immédiate.»

Louis Pasteur

Dans le présent numéro du Journal, Werner Kalow, l'un des pères fondateurs de la pharmacogénétique, écrit un compte rendu historique fascinant qui explique comment, il y un demi-siècle, lui et d'autres ont trouvé la cholinestérase plasmatique (pseudocholinestérase) et découvert que certaines personnes sont nées avec un enzyme défectueux qui les rend incapables d'hydrolyser normalement la succinylcholine. ${ }^{1}$

Ses souvenirs sont intéressants non seulement parce qu'ils placent l'anesthésiologie au centre, en lien avec la naissance de la pharmacogénétique, mais aussi parce qu'ils offrent un excellent aperçu des conditions de travail des chercheurs d'après-guerre et, surtout, parce 
qu'ils illustrent les obstacles techniques auxquels ils ont été confrontés. Kalow souligne certains dilemmes représentatifs de la recherche médicale et, à ce titre, son article présente aussi un message aux jeunes chercheurs d'aujourd'hui. Par exemple : que la recherche suit rarement une voie prédéterminée, mais qu'elle est intuitive et pleine de surprises ; que des rencontres fortuites amènent souvent dans un champ d'investigation particulier et, plus tard, à une nouvelle découverte fondamentale ; que, assez souvent, l'apparition de nouvelles connaissances survient simultanément à l'intérieur de groupes de recherche différents, mais aussi que des années de travail acharné précèdent habituellement cette percée ; que le travail d'équipe est important, sur une base internationale également, de même qu'avec d'autres centres et spécialistes ; qu'une connaissance approfondie de la documentation est vitale ; enfin, et surtout, qu'il est important de publier le plus vite possible pour avoir l'honneur d'être le premier.

La preuve apportée par Kalow et ses collègues, que certains patients ont un défaut de cholinestérase plasmatique déterminé génétiquement - un enzyme «résistant à la dibucaïne», ou enzyme atypique qui cause une réaction anormale à la succinylcholine - a eu un impact significatif sur la recherche clinique et de laboratoire. De ce fait, un énorme intérêt pour la cholinestérase plasmatique a été suscité, surtout chez les biochimistes et les anesthésiologistes, ce qui a conduit à la création de centres de recherche sur la cholinestérase partout dans le monde. ${ }^{2,3}$ Depuis, beaucoup de nouvelles méthodes biochimiques de classification de l'activité de la cholinestérase plasmatique et des phénotypes ont été mises au point. ${ }^{4-8}$ Néanmoins, la méthode du pourcentage d'inhibition à la dibucaïne de Kalow demeure la référence pour la classification des phénotypes. À n'en pas douter, la méthode de Kalow a résisté au temps, ce qui est plus qu'on ne peut en dire de la plupart des tests diagnostiques élaborés dans les années 1950. Cependant, avec les procédés modernes d'épreuves biologiques moléculaires, il est maintenant relativement facile de classifier le génotype de la cholinestérase plasmatique d'un patient avec une grande précision. ${ }^{9-12}$ On peut prévoir que ces procédés vont bientôt remplacer la méthode de Kalow - aussi dans des investigations plus courantes de la cholinestérase plasmatique chez les patients.

La découverte de Kalow a stimulé la recherche en laboratoire, mais a eu aussi une influence marquante sur la recherche clinique. Les chercheurs en laboratoire et les anesthésiologistes se sont trouvés à travailler ensemble de très près dans le but d'élucider l'importance clinique des différents phénotypes. ${ }^{13}$
C'est un bel exemple de la «recherche appliquée», longtemps avant qu'on invente l'expression dans le milieu scientifique.

Aujourd'hui, même si nous ne comprenons pas encore tout à fait la fonction physiologique de la cholinestérase plasmatique, cette coopération a permis d'ajouter beaucoup à nos connaissances par la découverte graduelle de plus de 40 mutations de la cholinestérase plasmatique et de leur importance pour les réactions à la succinylcholine et au mivacurium. À cet égard, nous pouvons déterminer avec une quasicertitude si une réaction apparemment anormale à la succinylcholine ou au mivacurium résulte d'un défaut génétique de la cholinestérase plasmatique ou s'il faut chercher la cause ailleurs pour bien traiter le patient.

Ce qui peut être encore plus significatif, c'est qu'il est possible de prédire comment un patient qui présente une mutation spécifique de la cholinestérase plasmatique réagira à ces deux curarisants. Sachant cela, nous pouvons actuellement offrir des conseils bien avisés aux personnes qui ont un défaut génétique de cholinestérase plasmatique et, par exemple, nous permettre d'émettre des cartes de mise en garde contre l'usage de succinylcholine et de mivacurium en doses normales. De nombreux patients et leur famille à travers le monde sont extrêmement heureux de savoir qu'il est possible d'offrir ce type d'examen. Un bon exemple est celui de 5000 patients du Danemark qui portent une carte de mise en garde contenant les informations sur le génotype de la cholinestérase individuelle et les détails de leur réaction anticipée à la succinylcholine et au mivacurium. Enfin, des essais cliniques prospectifs contrôlés ont démontré comment les cliniciens doivent traiter les patients avec un blocage neuromusculaire prolongé après une injection de succinylcholine ou de mivacurium. Cette recherche a montré, en particulier, l'importance d'un diagnostic rapide et précis de façon que le patient soit maintenu anesthésié jusqu'à ce que la fonction musculaire soit revenue à la normale. ${ }^{\mathrm{A}, \mathrm{B}}$

Les curarisants étant moins utilisés en général, et la succinylcholine en particulier, les mutations de la cholinestérase plasmatique transmises génétiquement vont naturellement jouer un rôle moins important

A Jensen FS. Plasma cholinesterase and the anaesthetist. New Aspects of Genetic Variants and Response to Succinylcholine. Ph.d. thesis, Copenhagen University, Copenhagen, Denmark, 1994.

B Gätke MR. Mutations in the Butylcholinesterase Gene and Their Significance for the Reaction to Mivacurium. Ph.d. thesis, Copenhagen University, Copenhagen, Denmark, 2001. 
dans la pratique courante de l'anesthésiologiste. La preuve en est le nombre de plus en plus faible de patients dirigés vers le Danish Cholinesterase Research Unit à la suite d'une réaction prolongée aux effets de la succinylcholine ou du mivacurium. Cependant, aussi longtemps que ces deux médicaments ne pourront être efficacement remplacés, l'anesthésiologiste au fait de la situation doit connaître non seulement l'existence des mutations transmises génétiquement, mais aussi ce que cela signifie et comment traiter un patient qui réagit anormalement à la succinylcholine ou au mivacurium. ${ }^{\mathrm{A}, \mathrm{B}}$

Il est évident que l'introduction de nouveaux médicaments en anesthésiologie, dont la biotransformation serait liée à la cholinestérase plasmatique, ne devrait jamais être ignorée à l'avenir. C'est peu probable toutefois, si l'on pense aux nombreuses autres possibilités de synthèse de médicaments offertes aujourd'hui et qui ne comportent pas d'hydrolyse par des enzymes pouvant être mutés génétiquement. Pour cette raison, il semble clair que dans 50 ans, la découverte de Kalow et sa méthode d'inhibition à la dibucaïne pour classifier les phénotypes de la cholinestérase plasmatique ne seront que d'intérêt historique pour les anesthésiologistes. Mais combien de découvertes et de méthodologies d'une envergure égale à celles de Werner Kalow sont encore valables après 50 ans ? La réponse est : pas beaucoup - ce qui situe à sa vraie place l'importance de sa contribution scientifique.

\section{References}

1 Kalow W. Atypical plasma cholinesterase. A personal discovery story: a tale of three cities. Can J Anesth 2004; 51: 206-11.

2 Whittaker M, Vickers MD. Initial experiences with the Cholinesterase Research Unit. Br J Anaesth 1970; 42: 1016-20.

3 Viby-Mogensen J, Hanel HK. Prolonged apnoea after suxamethonium: an analysis of the first 225 cases reported to the Danish Cholinesterase Research Unit. Acta Anaesthesiol Scand 1978; 22: 371-80.

4 Harris $H$, Whittaker M. Differential inhibition of human serum cholinesterase with fluoride: Recognition of two new phenotypes. Nature 1961; 191: 496-8.

5 Hanel HK, Mogensen JV. Urea inhibition of human pseudocholinesterase. A new method of detecting atypical pseudocholinesterase in homozygotes. Br J Anaesth 1971; 43: 51-3.

6 King J, Griffin D. Differentiation of serum cholinesterase variants by succinyldicholine inhibition. Br J Anaesth 1973; 45: 450-4.

7 Liddell J, Newman GE, Brown DF. A pseudocholinesterase variant in human tissues. Nature 1963;
198: 1090-1.

8 Evans RT, Wardell J. On the identification and frequency of the $\mathrm{J}$ and $\mathrm{K}$ cholinesterase phenotypes in a Canadian population. J Med Cand 1984; 21: 99-102.

9 Lockridge O, Bartels CF, Vaughan TA, Wong CK, Norton SE, Johnson LL. Complete amino acid sequence of human serum cholinesterase. J Biol Chem 1987; 262: 549-57.

10 Jensen FS, Bartels CF, La Du BN. Structural basis of the butyrylcholinesterase $\mathrm{H}$-variant segregating in two Danish families. Pharmacogenetics 1992; 2: 234-40.

11 Bartels CF, Jensen FS, Lockridge O, et al. DNA mutation associated with the human butyrylcholinesterase K-variant and its linkage to the atypical variant mutation and other polymorphic sites. Am J Hum Genet 1992; 50: 1086-103.

12 Jensen FS, Nielsen LR, Schwartz M. Detection of the plasma cholinesterase $\mathrm{K}$ variant by PCR using an amplification-created restriction site. Hum Hered 1996; 46: 26-31.

13 Viby-Mogensen J, Hanel HK. A Danish cholinesterase research unit. Acta Anaesthesiol Scand 1977; 21 : 405-12. 